\title{
15072
}

Sirvey of Land and mater Besources

plan of operation signed June 1960 Smenchent I(Eev.I) signed Jume 1960 Amended plan of operation June 1963 
Special Fund Contribution:

Government Contribution:

Duration:

jxecuting igency:

Cooperating Government isenoy:
$\$ 1,257,400$

Afghanis $23,518,000$

(equivalent of US $\$ 727,000$ )

Aéricultural station 5 years Survey 3 years

The Food and Lericulture Oreanization of the United Nations

Ministry of Agriculture Afghanistan

For the purpose of the Survey of Land and Nator Resources, and establishnent of an Agricultural Station to be undertaken by the Food and Agriculture Organization of the Unitod lations acting as Jrocuting Agoncy for tho United Irations Special Fund, this Plan of Operations shall be the Plan of Oporations provided for in irticlo I, paragraph 2 of the Agreement signed on 21 February, 1960 by the Governmont of Lfghanistan and the United Nations Spocial Fund.

I. Purpose and Description of the Project

1. The Purpose of the Project

1. To provido information nooded for tho improvemont of cxisting irrigation systoms and to supply an inventory of the comparativo land and water potentials of tho mejor rivor basins, including Kundoz, Kolcha, Kabul, Harirud, Farah aind othor rivor basins soloctod by the Govorninent with the view to help stimulato aericultural and conoral economic dovelopment. The project will silso dovelop in Kataghan Province a station and stafi for riold tostine of improved practices in crop production and animal husbandry, for trainine various lovels of oxtonsion vorkors for that and noighbouring provinces, for initiatins a soed multiplication schomo and to provide a pattern for dovelopment of similar facilities in othor parts of the country.

\section{B. The Project}

2. The project will coinprise two mutually supporting parts: the land and vater resources survoy and the agricultural station.

3. The land and wator rosources survey will includo tho Kundoz, Kokcha, Kabul, Farah and Harirud river basins, as well as other river basins selected by the Govomment. The survoy will provide, ultinately, a land and water rosources inventory, obtaincd through: 
(1) Study and survay of the important existing irrigation canals and oyotems in rolation to present land and water use and with a view to futuro improvomonts.

(ii) Flow mosuremont on rivers and existing canals ror tho assossment of their developront potential. Study of climate and moteorology.

(iii) Survey of possible storage sites on selectgd rivers with a view to improving their water potontial, topography, geology and wator manaģonont planning.

(iv) Reconnaissanco soil survoy and land classification in selocted. river basins with special omphasis on irrigation farming. A. toposraphic survey will be carriod out prior to tho soil survey, dofining the commandod areas.

(v) Land use study, based on abovo investigations and survoys.

(vi) Surveys carried out by other agencios will bo taken into consideration in the programming and then results incorporated in tho projoct report.

(vii) Aorial photography, photomosaics and contour maps available at tho Cartographic Instituto will bo usod for tho survoy.

4. A team of 10 oxports is required to carry out theso various aspects of the land and wator rosourcos survoy. Thoy will work with a toan of 24 Afghan, ongineers, soils tochnicians and agronomists, who after tho assistanco of the special Fund has onded, will continuo and expand tho survoy and operate, in particular, the hydrometric stations ostablishod with equipmont financed. by the Special Fund. Tho Iindings of tho wator and soil surveys will bo presented in the form of a proliminary development plan. This rill include (1) proposals for improvonont of the oxisting irrigation systoms (2) a tontative water managemont plan for soloctod rivor basins taking into consideration possible improvement in tho rivor regimos by storage (3) classification of soils in the selocted river basins with spocial roforonce to thoir suitability for irngation farming in the aroas commanded by tho rivers and (4) sonoral description of tho prosent land uso pattern and tontativo proposals for futuro land use for tho arcas which can bo takon into consideration for tho future availability of wator for irrigation. (5) A gonoral assossnont of tho power potontial of the . rivors correlated with the uso of wator for irrigation will also be undertakon. The exports assigned to tho survey projoct rill bo assisted by station stafi, particularly in describing the presont land uso pattom and in putting forward tontative proposals for land use in the future.

5. Whilo progress is boine made toward incroasing tho knowledge of soil and water potontialitios, cortain stops vill need to be undertakon to enwure realization of thoso potontialitios. Thore are at prosent practically no facilitios for field trials or training agricultural porsonnol in the ivorth of . Afghanistan and only vory limited facilitios axist in othor aroas. Trials 
under local conditions vill be required to determine the kinds of improved management practices which will result in increased and/or more efficient production, and thus may safely be taught to and employed by extension officers. Concurrently, local staff will have to be trained for the field testing and training vork and to conduct and supervise extension work. Finally a seed multiplication scheme for the major crops vill need to be initiated. These needs will be met through the establishment of a combined field station and extension training centre. Internationally recruited staff will initiate the testing, training and seed multiplication prograrnme but this staff will have local counterparts who will learn by working with the international experts, and also through study abroad made possible by the granting of scholarships. In will have to serve as the field tosting and training requirements, the station will have to serve as the focal point for all of the government's agricultural development activities in the area includins seed multiplication. Eventually, the local station staff will assume complete responsibility for these activities.

6. The agricultural station will include land for field testing of improved crop production practices, seed production, farm bulldings, repair shop, offices, classrooms and housing for starf and trainees. A suitable site of 250 acres has already been selected, topographically surveyed, and planned at Atabloqi on the Kunduz river, Kataghan Province. Empliasis will be placed on field trials and training of personnel for introduction of improved crop production practices and seed multiplication, with special attention being given to cotton, sugar beets and cereals.

7. Three categories of extension personnel will be trained at the station. Field level workers will receive one year of training in improved production practices and in extension methods appropriate for teaching and influencing local farmers to employ these practices. The training will take place on the station farm, in the classrooms and in an extension pilot area adjoining the station. A second category of extension porsonnel, the supervisors required at intermediate administrative levels, will undergo shorter periods of training in the classrooms but mainly in the oxtension pilot area under the guidance of the international extension expert. The third group of personnel to be trained. will be the subject matter specialists in the various fields who serve as sources of technical information an a Eidence for field and supervisory extension workers. This same group will eventually also handle the field trials and training at the station. The initial group of subject matter specialists will be trained by serving as counterparts to the international staff at the station and through study abroad. At a later stage short term refresher courses for subject matter specialists, for supervisory and field personnel; will bo conducted at the station. The station will initially train personnel for the Kataghan Province but by the tine Special Fund assistance has cuased, it is anticipated that the station will be in a position also to train personnel from neighbouring provinces.

8. The international staft will consist of 9 or 10 officers in the following fields: (1) agricultural training and station direction (project manager): and water requirements); (3) agronomy (all aspects of cotton cultivation and insect and disease control for firjd crops in general); (4) agricultural 
engineering (ferm layout, farm buildings, farm tools and machinery, drainage, irrigation) also. to supervise the maintenance of station plant and equipment; (5) aninal husbandry (animal proluction and management in goneral including draught animals) s (6) agricultural s..tension (to organize and supervise pilot extension project, teach extension met:ols and elementary agricultural economics); (7) a number of shorter term aericulturists. In sddition, members of the survey tearn would assist with an problems sssociated with laying out the irrigation system and other soil and water rroblens associated th stetion operations. A tean of 12 Af gilin a griculturists will serve as counterparts. Six of this group will be selocted for stuay abroad. An ajministrative officer will serve durinf the early part of the project to train $100 \mathrm{~s}$ administrative staff. Six four-year scholarships will be awardec. (2) agronomy (cotton, cereals and sugar beets); (1) agricultural sneinisering; and (1) agriculture I economies.

(1) animal husbandry;

(1) agricultural extension;

II. Woris PIan

\section{A. Purticipation of the Precuting Agency}

\section{(a) Resouroos Survoy.}

\section{Personnel Sorvices}
(i) Water development engineer (project manager)
(ii) Wydroerapher
(iii) Hydrometrist
(iv) Survey Engineer
(v) 2 survey assistants
(vi) 2 Soil Surver specialists
vii) Enginoering geologist
(viii) Land use plannine specialist
(ix) Aa hoc consultants

2. Equipment and Supplie:s

(i) Toporraphic equipment such as levels, theodolites, altimeters,

(ii) Dlanetable, telemeter, stereotop, staves, chains, etc. limioraphs.

(iij) Soj.z laboratory and field equiomont such as conductivity bridge, PII meter, flane photometer she other items of equipment as well as chernicals.

(iv) Camp aquipment (campbels, tailes, chairs, tents, etc.)

(v) $\quad 8^{-j e s p}$ type of transport vehiclos, 1 2-ton truck, all with

(vi) Tquipment and materia.i for preparation and printing of maps and reports. 
(b) Agricultural Station

3. Personnel Services

(i) Agricultural Training and Station Director

ii) Agronomist (sugar beets, cereals)

5 years

(iii) Agronomist (cotton)

(iv) Animal fis sbandry (draught animals and animal

4 years

3 years

(v) Agroduction) Engineer

3 years

4 years

(vi) Agricultural Extension

(vii) Agriculturists (agricultural specialists on

4 years

shorter term assignments, or for service as

3 years

consultants. These would be for shorter term work to help with peak work-loads or with more specialized agricultural questions connected with some of the following: sugar beets, cereals, cotton, farm forestry, livestock; plant protection, engineerine, irrigation, economic questions, training and extonsion. They also would help carry the overell agricultural work, particularly during the fifth year during the last part of the trengition to full gorernment responsibility).

(viii) One administrative officer (will be supplied to serve both parts of the project).

\section{2}

4 years

\section{Scholarships}

Six four-year scholarships will be awarded as follows: (2) agronomy (cotton, sugar beets, cereals); (1) agricultural engineering; (1) animal husbandry; (1) agricultural extension; and (1) agricultural economics. The scholarship holders would begin their studies in the fall of the first year of the project's operation. After completing their studies, they would return for permanent duty at the Station.

5. Equipment and Supplios

(i) Agricultural machinery and implements, purchase of draught animals and other livestock, small workshop tools and equipment, power gonerating set, etc.

(ii) Equipment and supplios for building, pumps, pipes for water supplies, small electric power station and wire.

(iii) 5 jeep-type of vehicles, one 3-ton truck, spare parts.

(iv) Irrigation equipment, such as gates, measuring devices. 
(v) Seed, fertilizers and insecticides.

(vi) Training and station equipment and supplies.

\section{Subcontracts}

The Executing Agency will carry out the project by direct employment of experts and direct purchase of equipment. However, subcontractors acceptable to the Government might be employed for part of the resources survey.

B. Participation of the Government
(a) Resources Survey

7. Counterpart PermonneI
(i) 1 co-manager (hydraulic engineer)
(ii) 8 civil ongineers or technicians and surveyors
iv) 3 agricultural engineers or agronomists
v) 4 draftsmen
(vi) 2 construction foremen
(vii) 9 drivers
(viii) 1 driver-fitter
ix) 1 administrative assistant
(x) 1 clerk
(xi) 1 secretary-typist
(xii) Labour

8. Equipment and Supplies
(i) Aerial photos and maps.
ii) Fiel, lubricants for transport vehicles.
(iii) Construction of river elauging stations
(iv) Miscellaneous small supplies

9. Services

(i) Supply of insurable small aircraft for reconnaissance flights.

(ii) Soils laboratory instellation and facilities, required for the carrying out of soil and water analyses in connection with the soil and hydraulic survey.

(iii) Offices for international and Afghan personnel and storage space.

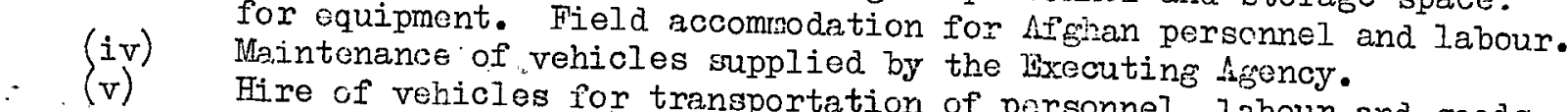
Hire of vehicles for transportation of porsonnel, labour and goods. 


\section{(b) Agricultural Station}

10. Counterpart Personnel
(i) Co-Maneger (agricultural trainee/station director)
(ii) 11 LEriculturists
(iii) 12 Drivers, tractor operators, fitters, greasors.
iv) 1 Administrative Assistant plus supporting staff
(v) Farm labour

11. Equipment and Supplies
(i) Bulldings.
(ii) Land for axporimental station
(iii) Agricultural implements
iv) Seeds; fertilizers and insecticides
(v) Fuel and lubricants
(vi) Miscellaneous

\section{Services}

(i) Maintenance of vehicles, mechines and other equipment.

13. Cost of freight of equipmont within Afghanistan

The Government will meet freight costs of all equipment supplied by the Executing Agency from the point of entry into the country to the project area. These costs shall include those of transport insurance, handling and storage within the country.

14. Government contribution to local facilities for Resource Survey and Agricultural Station

(i) In accordance vith Articlo $\nabla$, paregreph I of the agreement between the Specie? Fund and the Government, the Government will contribute the aquivalent of 139,643 towards local frailities.

(ii) This amount represents $15 \%$ of the total cost to the Executing Agency of foreign personnel, including cost of foreign personnel of sub-contractors, if such are employed on the project.

(iii) The amount montioned above shall be deposited by the Government into an account designated by the Secrotary-General of the United Nations and will bo made available as follows:

Equivalent of US\$18,577 on signaturs of the Plan of Operations

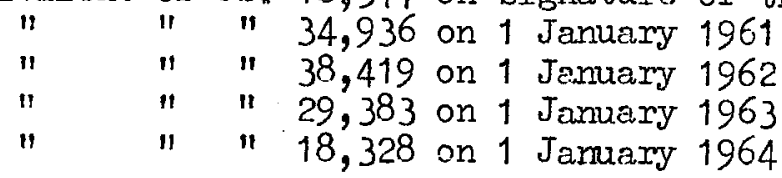


(a) othor Govcrnment contributions, to be paid in cash

(i) Cost of maintonanco ôे vohíclos and machinos, occasional hiro of additional transport will bo mot by the Govornmont in cash. The total amount, as show in tho budget and plan of oxponditure is for the survey, oquivalent of $\$ 10,000$ and for the agricultural station $\$ 37,000$. The total $\$ 47,000$.

(ii) The amount mentionod abovo shall bo deposited by tho Govornmont into an account dosignated by the Socrotary-Gonoral of the Unitod ITations and will be mado availablo as follows:

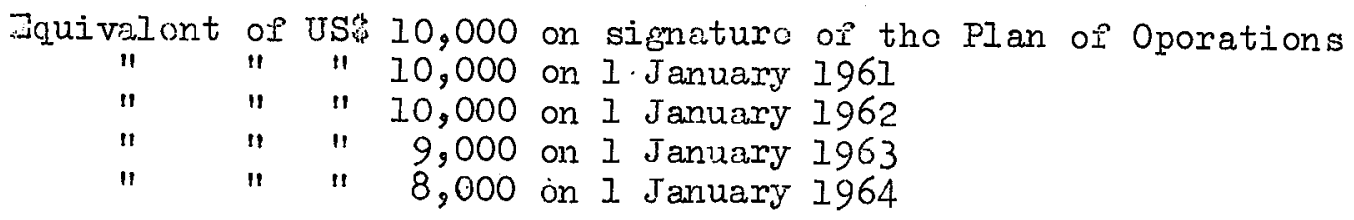

\section{Organization}

15. Ovorall responsibility for the organization and oxccution of the projoct rests with tho ijxecuting Agoncy who will plan and direct oporations through two project managers, who will bo solectod and appointed by tho Jxocuting Argency in consultation with the Governmont. A wator dovelopmont ongincor will bo tho projoct manacer for the rosources survey and an agricultural trainor station dircetor vill bo tho projoct manager for tho acricultural station and traininés contro.

16. The Govornmont vill appoint a co-manager for oach of the two parts of tho project, in consultation with tho Brocuting ligency. Tho co-manasors will cooperato wi.th tho projoct managors in tho cxocution of tho projoct. The comanagors will be roaponsiblo for tho sotting up proliminary arrangomonts agrood upon as woll as tho adrinistration of counterpart porsonnol suppliod by tho Govornmont for the oxccution of the project. The working arrangomonts for Governmont porsonnol on Gaed in the project shall bo worked out by the co-manarers in consultation with tho projoct managors.

17. A conmittoo rill bo formod by the fifinistor of Aericulturo undor his chairmanship irith tho participation of roprosuntativos of othor ilinistrics concernod. Tho manasors and co-manacers will bo oz officio nombors. This cormittoo will assist tho managers and co-managors in the implomontation of the project and cnsuro coordination of the activitios of tho various ministrics and thoir dopartinonts rolatod to the project. 
18. Under the general supervision of the Executing Agency, the Project Managers will be responsible for the detailed planning, administration and execution of tre project, including the timing and budgeting of the various elements, the preparetion of technical repcrts and the organization and supervision of related trainins programs. The project managers will al so be responsible for the coordination of the work of the various experts and grcups of exports. An administrative officer appointed by the Executing Agency will assist the Project Managers in the administration of the project.

19. The Government will appoint an administrative assistant to each of the two parts of the project whose dutios will include the keeping of project accounts, stores, ledgers and payrolls.

\section{Sequence of Operations}

20. The Executing Agency ahall commence operetion of the project upon written authorization to do so from the Managing Director of the Special Fund.

21. Immediately after signature of the Plan of Oporations by the Govermment, the Hxecuting Agency and the Special Fund, the Executing Agency shall undartake the recruitment of the experts and, if agreed with the covernment, shall enter into negotiation with a subcontractor for participation in the project.

22. At the same timo, the Gevernment shall appoint the two co-managers, acoetable to the Executing Agency.

23. Upon arrival of the Project Manager of the resources survey the Government shall supply to him aerial photos and aerial photo-mosaics covering the areas where the resources survey will be first carried out.

24. A general plan of survey sperations shell bo drawn up by the Project Nanager of the Land and Water Resources Survey in cooperation with the comanager and in consultation with the Government Committee not later than 6 weoks from the arrival of the projoct nangerer in the cuntry, or appointment of the co-maneger, whichever is lator. For this purpose the project manager, the tean nembers concerned, and the co-managers, should undertake reconnaissance flights over the river basins sclected for survey. The generel plan should include the list of river basins to be included in the survey, the sequence in which the individual areas should be surveyed and a genoral description of operations. Not later than two months after submission of this general plan a more detailed work plan should be submitted for the first yoar of operation:" In this plan staffing, equipment, transport, labcur requirement of the five groups (viz. hydrography, topography, soils, geology and land use) should be given in sufficient detail to ensure timely supply of materials and equipment, transport and lodging.

25. Similar detailed plans shall be dram up not later than 2 months before the end of each year for the comine year. 
26. In working out tho detailed plans due cunsideration shall be paid to climatic conditions in the various river basins.

27. The local authorities shall be kept informod about the movement of the teams and their requirements in acommodation, guidos, horses and local materials.

28. Immediately after signature of this Plan of Operations, the Government will begin preparations for making availelle farm buildings, repir shop, offices, classrooms, and housing fon staff and trainces. Plans for new constructions for the station shell bo finalized and agreed upon between the Executing Agency and the Government immediately after arrival in the country of the Project Manager. Tho Governmert shall then proceed as speedily as possible with the constmution of these buildings. No foreign personnel other than the project manager, agricultural engineer and administrative officer will be supplied until the Project Manager certifies that adequate installation and facilitios exist for the effective utilization of the additional staff mombers to be supplied by the Fund.

29. For the Agricultural Station, yearly plens of operations shall be worked out by the Project Nanager in consultation with the co-manager. For the first year this plan shell be prepared not later than two months after arrival of the Project Maneger; for the following years the plans shell be prepared not later than 2 months before the beginning of the year to which the plans relate.

30. The Project Managers in consultations with their co-managers should prepare at the earliest possible date a detailed list of equipment, materials, etc. required for the project. The list of foreign equipment and material to be supplied by the Executing Agency shall be sent to the Executing Agoncy which shall proceed imnediatoly with the placine of orders.

31. The project managers and co-managers shall jointly proceed with the selection of counterpart personnel and of administrativo purscnnel provided in the Plan of Operations.

32. Scholarsizips

The six candidatos for scholarslips will bo selected and sent abroad in the first year of operation (September 1960), and will roturn for permanent duty in June 1964.

\section{BUDGET}

1. In accordance with Article I, paragraph 3 of the $\Lambda$ greenent between the United. Nations Special Fund and the Government of ffghenistan, the total sum to be made availablo by the Special Fund through the Executing Agency to assist in tho execution of this project is $\$ 1,149,000$.

2. In addition to the above the United Nations Special Fund shall make available an amount of $\$ 1 \oplus 8,400$ to the Ezecuting Agency to defray the Agency costs. 
3. Unless othorwise agreed at any time by the Parties, this sum will be disbursed under the nain objects of expenditure in amounts and at times as scheduled in tho project budgot attached as Appendix I.

4. The total cost of the project to be borne by the Government is estimated at the equivalent of $\$ 727,000$ as show in the project budgot, as attached as Appondix II.

5. Out of this amount the Government shall pay in cash the equivalent of US 139,643 towards local facilities and of US 47,000 asainst the cost of servicing and maintonance of transport vehicles and machines and the occasional hire of trainsport vohiclos.

6. The remaining anount, oquivalont of US\$ $\$ \$ 0,357$, shall be contributed by the Government in kind unless otherwise agreod upon by the partios concornod.

IV. RTPORTS TO THE SPECIAI FUND

\section{Progress roports}

The IJxecuting Agency will submit to the Managine Director of the Special Fund semi-annual progress roports. The reports will givo a dotailed doscription on promress achioved in all aspocts of the project, eiving procress in quantative figuros, when applicablo.

\section{Financial reports}

Financial reports will be submitted by the Executing Asency to the Managing Diroctor of the Spocial Fund in a manner and at timos to be agreed upon by the Ianafing Director and tho Erocuting Agoncy.

\section{CONCLUSION}

1. Nliree months before completion of the project, a roport will be submitted by the Government to the Ixecuting Asency and the Spocial Fund on the benefits dorived from tho project and tho activitios planned by the Government to further the purpose of the project.

2. The equipment, materials and supplies by tho Bxocuting Agency will be consigned on loan to the Government, tho will assume responsibility for their safe kooping, transportation, operation and maintenance in tho interests of the project frori the date of arrival in Afghanistan until completion of the project or reassignment or transfor of title as forosoon in irticle II, paragraph 4, of the Agreemont betwoon the United Nations Spocial Fund and the Govornmont of Afghanistan concorning assistance from the Special Fund. 
3. The tochnical matorial obtainod during tho courso of the project will bo handod ovor by tho Jxocuting Agoncy to tho Afghan Govornment for appropriato utilization as agreod with tho Spocial Fund.

4. The accounts will bo closed as agrood botwoon tho Govornmont of Afghanistan and tho Spocial Fund within two months of the complotion of the projoct.

Agrood, on bohalf of tho Partios, by tho undorsignod:

1..9.9. 2.6.6. 15 . dato

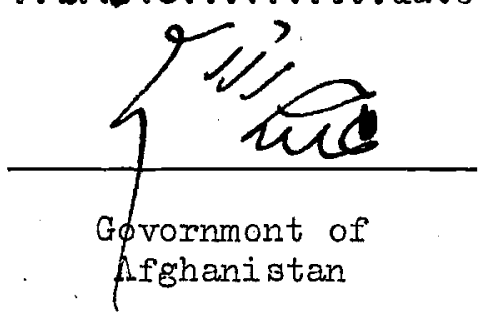

29. Inoms: 196.8 ate

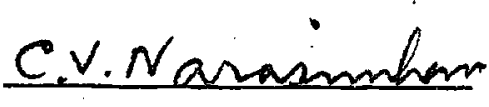

Unitod Nations Spocial Fund

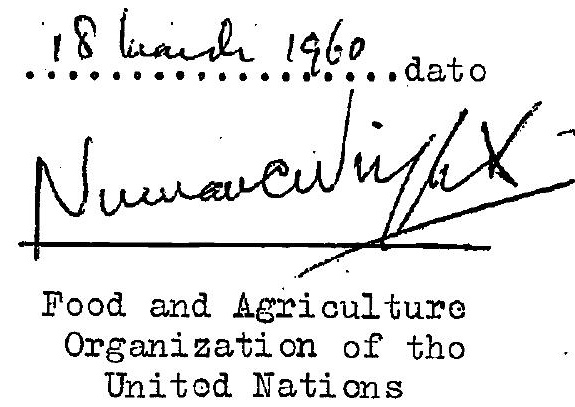

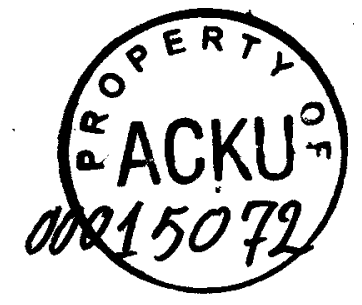

